\title{
Szakmai élettörténeti interjú Hanisch Erzsébettel
}

\author{
„Kész vagyok.”
}

Hanisch Erzsébet (H. E.): Nem bánom, ha közbeszóltok, ha valamit nagyon összekavarok, mert csak gondolatban készültem fel erre a beszélgetésre, amiről úgy tudom, hogy a szakmai történetemet kellene elmondani. Majd igyekszem, hogy ne legyek nagyon személyes, mert összefonódik a saját életem, de ne ijedjetek meg, nem arról fogok mesélni. Úgy gondoltam, hogy azzal kezdem, hogy elmesélem, hogy választottam ezt a szakmát. Szociális munkás vagyok, akinek a szakmai élete családgondozással telik máig is. Már elég öreg vagyok ahhoz, hogy valamilyen adminisztratív fönök legyek, de nem vagyok, dolgozom. Azt nem tudom, hogy fészkelte be magát az agyamba az a gondolat, hogy én a bolondokkal szeretnék foglalkozni. Amire vissza tudok emlékezni, hogy kamaszkoromban úgy olvastam regényeket, hogy újra elővettem a könyvet és rámentem ugyanarra a részre. Ilyen volt például az Egri csillagokban, amikor a két anya, a török meg a magyar átadják a gyerekeket, visszacserélik. Az egész Egri csillagokat biztos rosszul írtam meg az olvasónaplóban, de ezt a részt szinte kívülről tudtam. Ilyen volt a Jane Eyre-ben a Grace története, aki a földesúrnak a felesége és abban a padlásszobában van elzárva a külvilágtól, szégyellik is, büntudatot is keltenek benne. Én azt gondolom, hogy abban az időben, mikor ez a regény játszódik, valóban történt sok minden hasonló az elmebetegekkel. Erre voltam érzékeny, az elesett emberek iránt voltam érzékeny, nem tudom, hogy miért. Ami megfogott kamaszkoromban - a kamaszkor az a hatvanas évekre esett, én a háború utáni első generációban születtem. Még nem éltem a háború alatt, de a szüleim nemzedéke fiatal felnőtt volt ebben a krízises, kritikus, mindenféle bajt szülő helyzetben. József Attila volt még, aki belépett a lelkembe, nem tudom, miért, mert nem voltam erősen irodalmi érdeklődésü. Tizenöt évesen persze költő vagy festőművész akartam lenni és ilyen kezdeményeket írtam is és festettem is, de igazából semmit sem gondoltam akkor komolyan és tudatosan. Ilyen ösztönember voltam, mint a kamaszok nagy többsége. József Attilának néhány sora beleégette magát a lelkembe. Én annyit tudtam róla, hogy skizofrén volt, a hatvanas években ezt lehetett tudni róla, meg hogy öngyilkos lett. Később aztán megjelent egy csomó írás arról, hogy nem volt elmebeteg, meg az sem biztos, hogy öngyilkos lett, lehet, hogy csak elindult az a tehervonat, ami mögött ő át akart sétálni. Mindenesetre az én fejemben az a gondolat született meg, hogy a bolond meg a zseni ugyanaz. A Kosztolányi tér környékén laktam, ott volt egy ember, akiröl az a beszéd járta, hogy bolond, de ez látszott is, épp hogy csak spárgán nem húzott egy papírdobozt, egyébként minden módon látszott rajta. De azt is lehetett tudni, hogy nyolc nyelven beszél, tehát ez még jobban alátámasztotta, hogy a bolond az zseni, így ez nagyjából el is döntötte, hogy bolondokkal szeretnék foglalkozni. Azt, hogy milyen szinten, azt a középiskolai osztályzataim döntötték el. Semmilyen esélyem nem volt a továbbtanulásra, hacsak nem feküdtem volna neki. De a fiúk mindennél jobban érdekeltek, még a bolondoknál is. Érettségi után egy újsághirdetésre jelentkeztem ápolónőnek, az ORFI kórház hirdetett felvételt érettségizett lányoknak. Odamentem és az mondtam, hogy én az idegosztályra szeretnék menni, de ott azt mondták, hogy a hasi sebészeten van felvétel. Azt mondtam, hogy na jó, meg különben se tudtam nagyon a hatalommal ellenkezni, csak a hátuk mögött... majd, ha ott leszek, akkor majd átmegyek az idegosztályra. Ebből az is lényeges - nem csak rólam szól ez -, hogy akkoriban az ideg- és elmebetegségeket összemosták. A szavak is, hogy ideges 
vagyok, hogy ideg-összeroppanásom van, arra utalnak, hogy a szakma sem választotta külön az ideg- és elmebetegségeket. Mentem a hasi sebészetre, ahol a kórházi hierarchiát tapasztaltam meg, ez a hierarchia máig él az egészségügyben, és azt jelentette az én fiatal lelkem számára, hogy nekem férfiaknak elöre kell köszönni azért, mert ő kandidátus, én meg segédnővér vagyok. A szaknővért Ica nővérnek kellett szólítanom, éppen amikor a felnőtt életet el kellett volna kezdeni tanulni. Ezek nagyon meredeken érintettek, egy hónapot bírtam ott ki, lejárt a szerződésem és eljöttem. Ilyen pisi, kaki, epeváladék - ilyen dolgokkal foglalkoztam. Azzal fel is adtam. Annyit lehetett tudni, hogy a bolondok a sárga házban vannak, de én azt se tudtam, hogy van Lipót, van Lipótmezei út és a környezetben nem volt senki, aki útbaigazított volna, így nagyjából le is mondtam az ilyen terveimröl, és elmentem egy nyomdába, ahol jól éreztem magam. Alfákat meg bétákat rajzoltam be egyetemi jegyzetekbe, de jó társaságban voltam és ott tanultam meg sörözni, meg ilyenek... Egyszer csak az egyik bátyám, aki mezőgazdasági mérnök volt, azt mondta, hogy gyere, itt vannak a bolondok. Ez volt Pomáz, ami egy munkaterápiás intézet volt, és itt kezdődik valójában a szakmai életem, hogy odamentem tanfolyamos nővérnek, ami egy hároméves tanfolyam volt. Anyám utánam szólt, hogy ezt úgyse fogod befejezni, és akkor gondoltam, hogy akkor ezt befejezem, csak hogy rácáfoljak. És akkor egy olyan helyre kerültem, ami korábban alakult egy olyan eszme alapján, hogy a pszichiátriai betegnek nem a keze beteg, nem a lába beteg, a munka pedig építi a személyiséget. Ez ellen a lenini gondolat ellen, hogy a munka tesz emberré, nekem nincs kifogásom, mert a munka, az alkotás nagyon sokat jelent a személyiségünknek is. De ezt a munkát a mezőgazdasági munkában akarták megvalósítani, teljesen függetlenül attól, hogy az az ember, aki odakerült, az eredetileg milyen érdeklődésű volt, milyen végzettségü volt, ott a paradicsomot szedte az orvostól, a lakatostól, a segédmunkástól kezdve mindenki. A mezőgazdasági munkára jellemző az, hogy idénymunka, tehát novemberben, amikor érik az alma, akkor fagyos kézzel ki kell menni és le kell szedni az almát, függetlenül attól, hogy ki milyen antipszichotikumokat szed és milyen állapotban van. Az én bátyám mezőgazdasági mérnök volt, és itt is az összes szakmunkát egészségesek látták el. Igazából azt is mondom, hogy ez egy rabszolgamunka volt a pszichiátriai betegekkel, de az elképzelés nem volt rossz. Ráadásul akkor, a hetvenes években ezek nagyon durva gyógyszerek voltak, ma már sokkal lájtosabbakat szednek a pszichiátriai betegek. Akkoriban durva mellékhatása volt ezeknek a gyógyszereknek. Ez még az az időszak volt, amikor hatnapos volt a munkahét, tehát szombaton is délig dolgozott mindenki, így a pszichiátriai betegek is. Az az osztály, ahová én érkeztem, a pomázi munkaterápiás intézet, ott 150 embert ápoltak. Az ápolási idő évtizedekben is mérhető volt, tehát voltak ott emberek, akik már 15 éve ott voltak, meg olyanok, akik 2-3 éve, de olyan egy se, akit fél évig kezeltek volna, aztán rehabilitáltan visszailleszkedett volna. Tehát ez egy társadalomtól elszigetelt társadalom volt, helyileg is meghatározható volt, mert Budakalásztól nem ment oda semmilyen jármü, az intézmény a saját mikrobuszával vitte oda az ott dolgozókat is. Ilyen kis sziget volt a Duna partján, volt saját mosodája, azt hiszem, hogy ott helyben főzték a kaját is. Volt konyhája, de az árut megvásárolták valahol. Ez azért lényeges, mert egy ilyen belterjes világ volt. Én ráadásul a nővérszálláson laktam, ami egy téliesített faház volt. Öten laktunk benne, az egyikben hárman, a másikban ketten. Ott folyt az életünk, ami egy fiatal lánynak nem igazán kielégítő, de aztán ott nagyon jóba lettünk, meg nagyon akartuk megvalósítani magunkat. Amiben én aktivizálni tudtam magamat, az csak a tiltakozás volt, akár a szüleimmel, akár a társadalommal, akár az orvosokkal, akárkivel szemben én nagyon tudtam tiltakozni. Ezt azért elég udvariasan tudtam előadni, ezért nem rugdostak ki 
mindenhonnan. Itt is a tiltakozni valókat gyüjtöttem össze és semmit nem értettem ahhoz, amit csináltam, vagy amit csinálnom kellett volna, mert nem tudtam, hogy mi egy nővérnek a feladata. Akkoriban hétköznapi dolog volt az elektrosokk, amiröl remélem, hallottatok valamit, és már nem csinálták, de ott ismertem olyan embereket, akiknek lobotómia mütétük volt. Ezt ugye lehet ismerni a Száll a kakukk fészkére címü filmből. Az a munka melletti képzés, amire jártam - nagyon sajnálom, hogy ma nincs ilyen -, a munkahely szervezte és én munkaidőben, heti nyolc órában jártam erre a képzésre, ahonnan egyébként lehetett ötször hiányozni, míg a munkahelyemről egyszer se, szóval jó volt. És ott tanítottak, amit tanítottak, az érzékelést - a mai napig nem tudom, hogy a pszichológusoknak is miért kell inkább békát boncolni, mint az, hogy hogyan forduljanak ezekhez az emberekhez. Ami szerintem megalázó volt a betegek számára, hogy ott mindenki egyöntetüen az intézménytől kapott ruhákban járt, egy sötétszürke posztóruha, bakancs, a bakancsba kapca... Nagy különbség volt a fizetésben a tanuló nővér meg a szakképzett nővér között. Tanuló nővérként 1600 forintot kerestem, szaknővérként meg 2600-at, ami nem a kétszerese, de jóval több. Ilyen forradalmár lelkületü voltam, még két csajt rábeszéltem és így hárman mondtunk fel együtt. Azt írtuk a felmondásba, hogy sem manuálisan - ez azt jelentette, hogy az injekció -, sem morálisan nem érezzük magunkat alkalmasnak erre a munkára. Az a két lány is megmaradt az elmeszakmában, ugyanúgy, mint én, sőt az egyik tett egy kört más helyeken, aztán ugyanide visszament. Én meg elmentem a nyomdába dolgozni vissza, és született egy gyerekem 74ben. Akkoriban még nagy truváj volt, hogy házasságon kívül született, mert nem ez volt a szokás. Szemlesütve mentem a nőgyógyászhoz, hogy nincsen asszonynevem. A szüleim el voltak ájulva, de mégis fogadták az én drága, imádott... harmincnyolc éves most ez a gyerek, és ez alapvetően megváltoztatta a világhoz való viszonyulásomat is, tehát eltünt belőlem ez a harciasság.

Hogy kerültem Goldschmidt Dénes osztályára? Ennek az a története, hogy Pomázon dolgoztam, mondták, hogy jön egy vendég, Goldschmidt Dénes. Nem hallottam korábban a nevét, ő az utolsó gyerekparalízis-járványban megbetegedett. Természetes volt, hogy ha jön egy orvos vendég, akkor majd beül az orvosi szobába és ahhoz a nővéreknek semmi köze nincs. Nem is ágáltam ez ellen, mert magam is természetesnek vettem. És a Goldschmidt meg nem. Úgy köszönt ránk, úgy ment a folyosón mellettünk az orvos kíséretével, hogy ebből ezt a személyes érdeklődést megéreztem, annak ellenére, hogy nem emlékszem, hogy pár szót is váltottunk volna, vagy sem. Ö is elfogadta, hogy nővérek nem mennek oda, de ez a demokratikus aura körülvette. Utána hallottam, hogy neki is elmeosztálya van, de nem olyan, mint a mienk, ott nincs ilyen büdös, egészen másképpen vannak ott a betegek. Pomázról még azt is elmondom, hogy Duna-part, rengeteg szúnyog. Úgy le voltak gyógyszerelve, hogy a szúnyogcsípést nem vették észre, és ha éjszaka az egyik oldalán aludt, a másik csupa szúnyogcsípés lett. Ilyen méltatlan helyzet volt. De hogy a Goldschmidt osztályán nem így van. Visszamentem a nyomdába, szültem ezt a gyereket, egyedül voltam, meg a szüleimre támaszkodtam. És akkor úgy döntöttem, hogy nem tehetem meg, hogy ez az egy szakmám van, amivel tudok pénzt keresni, így megkerestem a Goldschmidtot. Nyolc hónapos volt akkor a fiam, kimentem Hidegkútra, és úgy éreztem, hogy hazajöttem. A korábbi életemben csak azt tudtam és tanultam egyre artikuláltabban kifejezni, hogy mit nem akarok, itt meg azt éreztem, hogy azt fogom megtanulni, amit akarok. Ennek volt egy szakmai része, de egy társadalmi része is, hogy bekerültem - egy demokratikus sziget volt ez Budapesten, ami nagyon nem illett bele a társadalmi környezetébe. Nem az volt, hogy rögtön tegeződtünk, orvos, nővér, beteg, mindenki, de azt éreztem, hogy számít, amit gondolok, számít, amit 
mondok, számít, ahogy érzem magam, amit én is átélhettem és a betegek is átélhették. Tehát a terápiás közösség, amit Goldschmidt Intaházáról hozott - Benedek István az Aranyketrecben leírja, ha hallottatok róla. Egy generációval idősebb ember volt a Goldschmidt, mint én, negyven-ötven körül volt. Intaházán akkor ö már létrehozott egy kis helyet, mert az elmebetegeket a korábbi rendszerekben kívül akarták helyezni, a korábbi tbcszanatóriumokat alakították át elmeosztállyá, ahogy a tbc-t is kívül helyezték, mert akkor még halálos volt ez a betegség. Intaháza is egy ilyen hely volt, hogy elég messze volt és egy ilyen saját kis társadalom volt, mint amit Pomázon megtapasztaltam, csak ott ez a terápiás közösség szellemében alakult ez ki. 75-ben mentem a Goldschmidthoz dolgozni, nem volt ismeretlen a világban a terápiás közösség, de nyugati országokban sem volt sok helyen megvalósítva. Sokkal több volt a klasszikus pszichiátria. Ennek társadalmi jelentősége is van, hogy hogyan engedi ezt meg a társadalom. Azt mondta a Goldschmidt, hogy Újszászon nem lehet nagyot alakítani, nem figyel fel rá a világ, és ezért pályázott meg egy budapesti osztályt, ami 70-ben indult és én 75-ben kerültem oda, amikor már kialakult rendszere volt a terápiás közösségnek. Úgy nézett ki, hogy pszichiátriai nővérek és segédnővérek, orvosok és pszichológusok alakították a teamet. Volt egy gazdasági személyzet, és a Goldschmidt azt mondta, hogy az igazi terápiás közösségben a gazdasági személyzet is benne volna. A 150 embernek hétvégente 3 látogatója volt, a többieket nem látogatták, évekig nem látogatták, az a három látogató is többnyire ugyanahhoz az emberhez jött, aki megtartotta a külső kapcsolatait. A jellemző az volt, hogy a család nem tudott vele mit kezdeni. Ezért persze nem szabad haragudni, mert a családot is meg kell arra tanítani, hogy hogy viszonyuljon ahhoz a helyzethez, mikor a családban valaki bizarr és bolondos dolgokat beszél. Úgy nézett ki a terápiás közösség, hogy nem hordtunk fehér köpenyt, ugyanúgy öltöztek a betegek is, mint mi, illetve ök lehettek szabadidőruhában ott, én meg nem, mert a városon keresztül mentem. A Goldschmidt nagyon kérte, hogy ne tegeződjünk, miközben azt képviselte, hogy az elmebeteg és a nem elmebeteg között nincsen szakadék. De hogy hol húzódik meg a határ, azt a társadalom húzza meg, vagy a külső, családi környezet húzza meg, hogy mi az, amit már nem tolerál, és ha nem tolerálja és nem tud mit kezdeni vele, akkor elkezdi kívül helyezni magán és valamilyen betegségnek elnevezni. Úgy tudja leírni ezt a problémát, hogy a pszichiátriai betegek megátalkodottak abban, amit csinálnak. Ök főleg az íratlan szabályokat nem tartják be, nem elsősorban jogellenesen viselkednek, hanem ahogy szoktunk viselkedni egy társaságban, ők nem úgy viselkednek. Túl azon, hogy hallucinációik vannak, meg nagy téveszmerendszereket alakítanak ki, a hétköznapi magatartásuk az más. Tehát ha elmész egy buliba, ott vannak gátoltabbak meg kevésbé gátoltak, hülyére részegedők meg középre penderülők, de ő a gátoltnál gátoltabb, a kritikátlannál kritikátlanabb, tehát pontosan fogjátok érezni, hogy vele valami baj van. Ezért én nem bánom, ha ezt a betegség szót használják, bár nagyon különbözik a tüdőbajtól meg a többi szomatikus betegségtől. Tehát én úgy gondolom, hogy a skizofrénia az érzelmi élet betegsége, az intellektus nagyon sok esetben azért nem tartott meg, mert beszükül az élettere, nem megy, nem mozdul, kerüli a konfliktust, így izolálódik, az izoláció meg csökkenti az intellektust. Nem tud olvasni, mert a gyógyszer sem engedi, hogy ő tartósan odafigyeljen valamire. És akkor a Goldschmidt ezeket mondta és én ittam a szavait, és ez egy olyan hely volt az életemben, ahol nagyon jól éreztem magam, ahol az én szégyenteljes szülésem... tehát lehettem büszke a gyerekemre, mert egyébként csak otthon lehettem büszke a gyerekemre, de bárhova mentem, Hanisch Erzsinek hívtak és az olyan ciki volt, hogy nem voltam férjnél. De aztán később szerencsére úgy alakult a társadalmi környezet, hogy most már egyáltalán nem ciki az ilyesmi. A fiamnak sem 
kellett megélnie, mikor már ezt felfogta, hogy ö különbözne a többiektől, mert az anyja házasságon kívül szülte. Azért nem tudok eltekinteni a saját életemtől, mert végig segítette a magánéletemet, hogy ezt a szakmát választottam, hogy jobban megértsem, jobban toleráljam. Tehát amit én ott a Goldschmidtnél tanultam - magát a közösséget tanultam, hogy hogyan válnak a kapcsolatok kölcsönössé, hogyan kell nekem kezdeményezni, hogy kölcsönös legyen a kapcsolatunk, kit tisztelhetek a másik emberben, függetlenül attól, hogy ő kolléga vagy beteg. Mi az ő erőssége, hogy tudnám öt megszeretni, mert ha nekem ez sikerül... Vagy nem is megszeretni, hanem tisztelni, mert a tisztelet a lényeg, az elismerés. Mert akkor majd ö is engem... Ezt viszonozni fogja. Ha mentek bárhova - nem csak az elmebeteg környezetben -, ezt mindenhol megtapasztaljátok, hogy ha valaki azon sír, hogy öt nem szereti senki, az azt jelenti, hogy ő nem képes szeretni senkit, mert ha szeretünk valakit, az viszonozni képes ezt. A Goldschmidt persze húzott határt, hogy meddig szimmetrizáljuk a kapcsolatunkat, tulajdonképpen ez tilos volt, de ő maga... Újszászon egy betegböl lett a felesége, tehát ő maga is bekavart a személyes terébe, de éppen ezért nagyon féltett minket attól, hogy beleszerelmesedünk betegekbe és összevissza keveredik az egész. Ilyen híre is volt Hidegkútnak, hogy ott nem lehet tudni, hogy hány nővér hány beteggel fekszik össze. Ez nem így volt, de nálunk erről kellett beszélni, más helyeken meg nem beszéltek róla. Tehát összekavarodtunk érzelmileg, és ez volt a Goldschmidt felelössége, hogy ebben érzelmileg navigáljon bennünket. Az, hogy ha valaki kezdöként érzelmileg belebonyolódik egy ilyen... túlságosan részt vesz érzelmileg, vagy bevonódik... és ez a szociális munkára is vonatkozik, például ha a kliense az anyjára hasonlít, és akkor az anyjával kapcsolatos játszmáit kezdi a klienseivel játszani. Ezeknek az átbeszélése mind kell ahhoz, hogy később aztán tudj jobban határokat vonni. Ezt nem lehet megúszni, ezt nem lehet elméletileg megtanulni. Hogyha meg nagyon elválasztod magad érzelmileg, akkor meg a hivatalnokság irányába tartasz, és az meg sokkal rosszabb, mint ha ilyenfajta hibákat követsz el. És akkor én 15 évet lehúztam a Goldschmidtnél, én onnan akartam nyugdíjba menni, nekem semmilyen más vágyam nem volt, hogy mást csináljak, akkor már nem akartam pszichológus se lenni, mert még ez a szakma volt a pszichiáter és a pszichiátriai nővér mellett. De ez nekem nagyon megfelelt, mert egy személyesebb kapcsolat az nekem jó volt. Itt csak a pénz volt baj, szerettem volna orvosi fizetésért ezt csinálni, de ez így jó volt nekem. És akkor volt a Goldschmidtnek nyugatnémet szakmai barátsága, jött ide a nyugatnémet professzor - nem tudom a nevét, mert ezeket nem tudom megjegyezni - és hozta a teamjét és jöttek emberek, akik azt mondták, hogy ők ugyanezt csinálják, mint itt a nővérek, de ők szociális munkások. Mindez a nyolcvanas években. Mi vezettünk szocioterápiás csoportot. Hallom, hogy Németh Laci is fog jönni ${ }^{1}$, ő csinálta ezt, müvészetterápiát, ilyeneket. Beletanultunk, saját élmény először, co-terapeutaként aztán terapeutakét, játékcsoport, a Benedek Laci-féle könyv forgalomban van azóta is, ő arról írta, amit ott csináltunk. Co-terapeutaként vettünk részt nagycsoporton. A nagycsoport azt jelentette ott a terápiás közösségben és máshol is, hogy mindenki részt vesz, minden beteg és a személyzet minden tagja, kivéve a gazdasági személyzetet. Ez a demokrácia gyakorlása tulajdonképpen, a fó funkciója mégis a házirend. A nagycsoporton lehet megbeszélni, ha valaki erősködött délután, vagy leitta magát, vagy lebolondozta a másikat. Szóval mindent, amit a közösség nem tür, azokat a magatartásokat ott próbáltuk visszagyürni a helyére, hogy megértettük, hogy ő tulajdonképpen nem is a másikkal küzd, hanem az anyját látja benne. Ilyen konfliktusok mindenütt vannak. Itt 60 ágy volt és 30

\footnotetext{
${ }^{1}$ A vele készült interjú egy korábbi lapszámban jelent meg, http://parbeszed.lib.unideb.hu/file/2/585a40d014098/szerzo/NeMETH_Linterju.pdf .
} 
bejárós beteg. Ott azt is megbeszéltük, ha azt látták a szobatársak, hogy öngyilkossági veszély van, tehát egy csomó mindennek a terepe volt ez. Két ember vezette, a nővérek is lehettek co-terapeuták, terapeuták nem. Az akkori külső szabályok szerint pszichológus sem lehetett, pszichológus sem vezethetett terápiás csoportot, csak pszichiáter vezethette, de persze ott nálunk lehetett, tehát a Goldschmidt eltért ezektől a szabályoktól. Ez egy nagyszerü sziget volt, az volt a hátránya, hogy ez egy demokratikus sziget volt, a társadalmi környezet inkább diktatórikus volt. Nem egy zsarnoki környezet volt, de hogy magamról felelösen gondolkodjak, vagy annak a hatásait megnézzem, amit müvelek, az kívül nem volt szokás. Ha az ember elment a saját ügyeit intézni, akkor sírva jött el onnan és még be se csapta az ajtót, vagy még jobban becsapták. Egy ilyen társadalmi környezetben ez egy sokkal kiválóbb helyzet volt, sokkal testhezállóbb, nekünk, akik ott dolgoztunk meg a betegeknek is, és ezért volt, hogy ök nem nagyon akartak hazamenni, mi meg szerettük volna, ha fél évnél hosszabb ideig csak kivételes esetben marad valaki. Voltak ott olyan emberek, akik már előtte tíz évet a Lipóton éltek, és a külső életre már nem voltak alkalmasak. Minden pszichiátrián voltak ilyen emberek. Aztán elkezdett elterjedni, lett Pécsett is, Szolnok mellett is, tehát azt gondoltuk, hogy ez fog terjedni. Amikor a Goldschmidt elment nyugdíjba - ő egy elég beteg ember volt, nemcsak ez a béna lába, hanem tbc-s is volt korábban. Ö egy zsidó ember volt, aki a második világháborús krízisben szerzett ilyen betegségeket. Elment nyugdíjba, majd két-három év múlva meg is halt. Mikor ő elment nyugdíjba, akkor mi azt szerettük volna, ha az adjunktus, aki ott dolgozott velünk, ő legyen a vezető, de ezt nem sikerült elérnünk. Akkor volt a rendszerváltás, kilencvenben jöttünk el. (Ránéz az órára.) Jézusom, az idő... Mert nekem ez a szívügyem és még a szociális munkás létemre rá se tértem. Mindenesetre ott megpályáztatták, nem fogadták el az adjunktus, Varga Pál pályázatát, mert ő nem publikált eleget. A Goldschmidt se, nem is tudok nektek töle irodalmat ajánlani, ö se publikált vagy alig publikált valamit. Elfogadták egy átlagos főorvosnak a jelentkezését, nem akarok belemenni, mert rosszakat fogok mondani róla és nem érdemli meg. Bárki pályázta volna a Goldschmidtot, aki személyében egy karizmatikus ember volt, nem tudta volna senki pótolni. $\mathrm{Az}$ átlagos ember pszichiáter volt, addig egy vidéki osztályt vezetett, őt is vonzotta a Goldschmidt-féle pszichiátria, de nem tudta ő ezt személyiségében folytatni, bár a rendet nem bántotta, maradtak a nagycsoportok, a kiscsoportok és mindenféle terápiás színterek. Ilyeneket csinált - amihez ő szokva volt, de ami nekem teljesen idegen volt -, hogy egy rossz állapotú pszichiátriai beteget győzködtünk és akkor azt mondta, hogy hozzak egy „Cvitamint", ami egy erős pszichiátriai szert jelentett. Mi soha nem hazudtunk egy olyan embernek, aki elvesztette a realitással a kapcsolatát, még hazudni, az olyan, hogy belerúgsz valakinek a seggébe. Ha annak a gyógyszernek a nevét mondom, amit ő nem szívesen vett be, akkor még fél órával tovább tartott volna a győzködés, ezt a fél órát kímélte meg az átlagos fóorvos magának. Valaki odatette a rokonát, akit nagyon rendesen gondozott addig az otthonában, mert kiment Amerikába, és Amerikából odaszólt, hogy mégse jönne vissza, és akkor ezt a rokont el kellett tennünk egy elme-szociális otthonba. Kinéztük térképen, hogy hol van az, valahol délen, és erre azt mondta, hogy a Balaton-parton van, hogy könnyebben beszálljon abba a buszba, ami őt majd elszállítja. Egyszerre felálltunk húszan és szétszóródtunk.

Ekkor, kilencvenben kezdtek - akkor már volt néhány családsegítő, ezt talán tanultátok, 85től voltak, de nem volt minden kerületnek. Én elmentem Tündérhegyre, ami szintén egy terápiás közösség volt, de nem az általam imádott elmebetegekkel, hanem neurotikus betegekkel foglalkoztak ott. És akkor mi, a hidegkútiak, együtt maradtunk, összejártunk, 
összeesküvéseket szerveztünk. Előtérbe került a családsegítő. Volt ismerősünk a XII. kerületben, a Nevtanos pszichológus, és ő mondta, hogy az akkori polgármester, akinek pszichológus volt a felesége, tudta, mi a családterápia, mi a családsegítő. És akkor ezzel a maggal indult a családsegítő, nyolcan dolgoztunk ott azokból, akik ott kiléptünk Hidegkútról, és nem is volt más munkatársunk, tehát az a nyolc ember mind egy tőröl fakadt, az az adjunktus, akit korábban nem neveztek ki, az lett a családsegítőnek a vezetője. Ami nagyon érdekes, az a képzés, hogy akkor voltak harmadévesek az első szociális munkások. Addig egy volt Magyarországon, aki külföldön tanult ${ }^{2}$, meg Göncz Árpádnak a felesége végzett szociális munkás volt, mert valamikor a negyvenes években, míg ez az egypártrendszer ki nem alakult, volt egy pár évig szociálismunkás-képzés. Az adjunktusnak a felesége volt a XII. kerületi ideggondozónak a föorvosa, mi az első klienseinket onnan kaptuk, azokkal tudtuk, hogy mit kell csinálni, hogy mi a szociális munka, azt részemről nem tudtam, be is voltam szarva ettől. Mert mi kifestettük magunknak azt a helyet, amit kaptunk az önkormányzattól. Tehát ott a sör, a cigi, a falfestés, és akkor beállított két ember, hogy ők a börtönből most szabadultak. És akkor én olyan boldog voltam, de mondtuk, hogy még nem vagyunk nyitva és gondoltam, hogy te jó Isten, csak vissza ne jöjjenek. Mit fogok én mondani? Főleg az izgatott akkoriban, hogy valaki azt mondja, hogy menjek ki a lakásából, mi lesz, ha olyanokat kérnek, ami fölött én nem rendelkezem, például a lakásínségre, a húsz éve tartó alkoholbetegségre nekem semmilyen válaszom nincsen, hogy mit kell akkor kezdeni egy szociális munkásnak. Volt egy pár családsegítő már, az Esély például, azokat elmentünk meglátogatni, de ott nem engedtek be azokba a helyzetekbe, ahol ők találkoztak az ügyfeleikkel - teljes joggal egyébként -, csak beszéltek az ügyfeleikről, az önkényes lakásfoglalók mozgalmára emlékszem, meg ilyenekre. És akkor kezdett az egyetem, és talán mert Göncz Kinga, aki itt dolgozott, ismert engem, ezért mert mint tereptanárt felhasználni. Engem, akinek középfokú végzettsége volt csak... és akkor legyek okosabb, miközben ki se találtam még, hogy mi az a szociális munka. Ez egy ilyen kezdeti stádium volt. Akkor mindenféle humán diplomával is lehetett még csinálni, mert olyan kevés volt, vagy nem is volt egyáltalán végzett szociális munkás. Aztán lett egyre több, és lett minden kerületben. Megszerettem a szociális munkának azt a részét is, ami nem a pszichiátriai betegekkel foglalkozik, sőt az, amit én azon a területen tanultam, hogy hogyan tudok érzelmileg azonosulni, ha intellektuálisan nem is tudok, hogy ne azt vegyem elö, hogy „b... meg, miért nem csinálja?”, hanem hogy azzal érezzek együtt, hogy ö miért nem csinálja. Tehát ami számomra evidens lenne, vagy ami az én eszköztáramban szerepel, hogy az miért nincs az ő eszköztárában. Most meg abban a kényelmes helyzetben vagyok, hogy van egy közösségi pszichiátriai gondozás, amiben én félig-meddig részt veszek, és van egy pszichiátriai problémával élők nappali intézménye, amiről nem tudom, hogy hallottatok-e hogy milyen, mindenesetre az ideggondozóval szoros kapcsolatban a pszichiátriai problémával élökkel foglalkozunk. Már a beteg szót levetkőztem magamról, ezt már nem mondjuk. Foglalkozhatok velük a családsegítő munkatársaként is, nem vagyok vezető, de munkacsoport-vezető vagyok, mert azt már nem lehetett megoldani, hogy ne legyek, ami azért valamennyivel több pénzzel jár és ezért vonzó is. De a feladat az nekem sokkal jobban megy informálisan, mert most már mindenkinél idősebb vagyok, és akkor is hallgatnak rám, hogy ha én azt nem csoportvezetöként mondom. Csoportvezetöként visszajelzést adni az számomra nagyon nehéz feladat, mert kétszer annyit számít a szavam, mint amennyit én akarnék mondani. És akkor sírva fakad, amit én annyira nem szerettem volna, én az mondom,

\footnotetext{
${ }^{2}$ Hegyesi Gáborra utal.
} 
hogy a visszajelzés az ajándék, akkor is, ha fáj. És most befejezem, mert most az jön, hogy Ti kérdezzetek.

Kérdés: Hidegkúttal nincs is azóta kapcsolatod?

H. E.: Hidegkút megszünt azóta, ezekkel a hidegkúti kollégákkal van kapcsolatom, mert még mindig hárommal együtt dolgozom, ebben a teamben ilyen őskövületek vagyunk, ami okoz is feszültséget. Az átlagos föorvos vezetésével müködő osztályt megszüntették, nem az ő hibájából, hanem a tulajdonviszonyok miatt, tehát ez Klebelsberg Kunónak a téli vagy nyári rezidenciája volt. Nagyon sokan fordultak meg ott. Én 15 évig voltam ott, de két-három év alatt is magába tudta szívni valaki, ami ott történik. Én a 15 évemmel már úgy is éreztem, hogy én már alakítója is voltam annak a helyzetnek. Bugarszki Zsoltot ismeritek, ö is dolgozott ott, már az átlagfőorvos idején, de akkor még megmaradt az a hidegkúti varázs. Még mindig könnybe tud lábadni a szemem, ha erre gondolok - amúgy is könnyen. Én úgy gondolom, hogy a rendszerváltásnak a nyertese vagyok, ami egybeesett a hidegkúti krízissel. Én a szociális munkában találtam meg azt, hogy én önállóan veszek részt az esetkezelésben. Csináltam egy iszonyú jó színházi előadást, a Bicska Maxit előadtuk Hidegkúton, miközben semmi közöm a színészethez. Magam is katarzist éltem át. Ez volt az én nagy alkotásom, de egyébként egyes emberek életében csak hozzávetőleg vettem részt. Jóban voltunk, pingpongoztunk, kergetőztünk, felolvastunk, rádiós csoportot csináltunk, de egy ember életét nem kísértem. Erre voltak a pszichológusok, pszichiáterek kitalálva. A szociális munkában ebben is valami erőt szereztem magamnak és most már szeretem, hogy egy ember életébe beavatkozok önállóan. A szociális munkának ezt a problémáját, hogy én beavatkozom egy idegen embernek az intim terébe, és ezt én akkor is észreveszem, ha nem klienssel beszélek, hanem a férjemnek odajön egy barátja, aki elhozza magával a feleségét - ezzel nem tudok mit kezdeni. Attól, hogy ők barátok, mi még nem biztos, hogy barátok leszünk. És akkor megyek bele ebbe az interjús technikába és hajnalig beszélgetünk. Nem kéne ezt így csinálni, lehetne az embernek mással elütni... zenékről beszélni, mikor ilyen helyzetbe kerülünk, és nem jó, hogy tudom, hogy mi baja volt az anyjával. A kiégést azt sohasem értettem. Ha útravalót lehet nektek mondani, nekem nagyon fontos volt, hogy szeressem a fönökömet. Ez még a goldschmidti hagyomány. Különben nem tudok együtt dolgozni vele, nem akarok olyan teamben lenni, ahol majd megbeszéljük, hogy ö miért hülye... Ma nem az a helyzet már mint én, hogy 15 évig az egyik helyen, a másikon 22 éve vagyok... Ahogy én ráláttam az ő problémájára, úgy sokkal jobban ráláttam a sajátoméra is. Ugyanezen a sínen vagyok, nyolc éve ugyanazért b...gatom a férjemet, és aztán elkezdtem én magam elrakni a 43-as cipőket az utamból, és már a végén nem is voltam amiatt dühös, hogy ezt most öhelyette csinálom, hanem ez az én igényem, és ha nekik ez nem igényük - mert a két fiam is ebben a lábméretben van... Ilyen módon tanultam meg békésebben élni saját magammal. Az egészségügyi szociális munkás az ott beépült a hierarchiába, az a nővér és a tanulóorvos közötti helyet foglalja el, soha nem lehet saját ötlete, vagy vannak olyan osztályok, ahol nem lehet saját ötlete, hanem csak megszervezi, hogy ki kerüljön otthonba és ki legyen gondnokoltatva - van ilyen is. De a legtöbb szociális munkás helyen a demokrácia attól tud érvényesülni, mert egyforma vagy nagyjából egyforma végzettségü emberek csoportja dolgozik együtt. És akkor nagyon nagy baj a hierarchizáltság, nagyon sok baja lehet az embernek, ha olyan helyen dolgozik. Persze érdekelne, hogy Ti hogy kerültök ide, elmondjátok?

(Egy hallgató elmondja, hogy pszichológiát szeretne majd tanulni.) 
H. E.: Lehet, a családterápia az nyitva áll a szociális munkásoknak is. Az én családsegítőmben úgy indultunk, hogy a nyolcból öt volt pszichológus, illetve pszichiáter, hárman voltunk nővérek, mert akkor még nem voltunk szociális munkások. Most ez az arány már nagyon megváltozott, már harmincan vagyunk, de ez megmaradt, hogy ilyen pszichológiai szemléletü. A XII. kerület az egy értelmiségi kerület. A klienskörünk az hasonló, mint a VIII. kerületben, csak amit ők átélnek, az a különbözöségük. Tehát egy elit környezetben szegénynek lenni, egy elit osztályban szegény diáknak lenni az sokkal nehezebb, mint a hasonlóak között. Van most is pszichoterápia, családterápia nálunk.

Kérdés: A pszichiátriai betegek nappali ellátása a családsegítőn belül működik?

H. E.: Igen, a mi nagy teamünkbe beletartoznak, a családsegítő hozta létre. Először a gyerekjólétit, a törvénnyel együtt, van ifjúsági terünk is, az másfél éve müködik, ott kamaszokat, 13 és 18 év közötti utcagyerekeket fogadunk. Így együtt van, igen. A közösségi ellátásban és a klubban csak szociális munkások dolgoznak. Tehát kapnak pszichoterápiás segítséget, ha ők kérnek, de ez nem a fiatal és kezdődő pszichiátriai problémák idején van, hanem amikor már krónikussá vált. Tehát amikor ő már rokkantnyugdíjas, de be tud még járni egy ilyen klubba, és olyankor már olyan sok terápiás teendő nincs velük. Rendszerszemléletben dolgozunk, az elmebetegséget is tünetnek tekintjük, és nem az elmebajjal akarunk valamit kezdeni, hanem azzal a környezettel, ahol ez a betegség fenntartódik. Nem is annyira az okaival, hanem hogy mi az, ami fenntartja. Ezért csinálunk most hozzátartozói csoportot, mert legtöbbször a hozzátartozók is sérülnek, az ő életterük is beszükül. Szégyellik magukat a vendégek előtt, ezért izolálódnak ők is, és ez az anyai érzés nagyon sérül, ha a gyerek pont akkor, amikor a leválás időszaka van, akkor válik beteggé és ezzel megakadályozza a leválást. Hogyan tudja mégis elengedni a kezét, ha beteg is? Ha meg ott marad, akkor még negyvenéves korában is megkérdezi anyut, hogy hajat mosson-e? Tehát ezek pszichés tartalmak, amivel a szociális munka foglalkozik. De szerezzél pszichológusdiplomát is. Egy pszichológus nem akkor lesz pszichológus, amikor elvégezte, hanem amikor egy csomó pénzt kifizetett a klinikusira, a pszichoterapeuta-képzésre, a családterapeuta-képzésre, tehát olyan 45 éves kora körül kezd el keresni pénzt, míg a szociális munkás bátran nekivághat még ilyen képzések nélkül is. A klinikusi képzés nem sokat tesz hozzá, csak kötelező elvégezni. A szociális munkában mehetsz a saját érdeklődésed mentén és nem kell különféle jogosítványokat szerezned. Ha elkezded a munkát, akkor mellette tudsz tanulni. Én magam 47 éves koromban szereztem az első diplomámat, és azt is csak azért tudtam megszerezni, mert olyanokat tanultam, amiket már tudtam. Igazából rendszerbe foglalódott az, ami az agyamban volt és azt már nem volt olyan nehéz megtanulni. Buktam is középiskolában, nem volt jó fejem, később meg jó volt. Végül is a szakma szavait kell megtanulni és a saját rendszeredbe beilleszteni valahogy. Kész vagyok. 